\title{
The Microbial Status and Physico-Chemical Pollutants Studies of Rivers Owan and Evbiobe in Edo State, Nigeria
}

\author{
Oyakhilome Gloria Irenosen $^{1}$, Ajiwe Vincent Ishmael Egbulefu ${ }^{1}$, Akinola Olufemi Korede ${ }^{2}$ \\ ${ }^{1}$ Department of Pure and Industrial Chemistry, Nnamdi Azikiwe University, Awka, Nigeria \\ ${ }^{2}$ Department of Civil Engineering, University of Ibadan, Ibadan, Nigeria
}

Email address:

gloyaks@yahoo.com (O. G. Irenosen)

To cite this article:

Oyakhilome Gloria Irenosen, Ajiwe Vincent Ishmael Egbulefu, Akinola Olufemi Korede. The Microbial Status and Physico-Chemical Pollutants Studies of Rivers Owan and Evbiobe in Edo State, Nigeria. Science Journal of Analytical Chemistry.

Vol. 7, No. 2, 2019, pp. 57-64. doi: 10.11648/j.sjac.20190702.13

Received: May 23, 2018; Accepted: April 28, 2019; Published: July 11, 2019

\begin{abstract}
The areas of study are Rivers Owan and Evbiobe, which transverse respectively through Owan East and Owan West Local Government Areas of Edo State, Nigeria. Owan river is a washing zone for automobiles of all sorts on daily basis while a major market site is located behind Evbiobe river; thus exposing the rivers to high level of quality degradation and bacteriological pollution. The rivers serve as drinking water source and other domestic uses to the communities around the study areas. Water samples were collected at ten locations within Rivers Owan and Evbiobe over a period of twelve months, covering both dry and wet seasons. The water samples were analysed for water bacteriological and physico-chemical characteristics using methods prescribed by APHA (1998), Aiyesanmi (2008) and Oyakhilome et al. (2012). These rivers were highly polluted with bacteria load as observed in the results of the study when compared with their guideline values. The statistical analyses conducted on the physico-chemical parameters revealed high level of significant difference $(p<0.05)$ between wet and dry seasons' values for all parameters except Total Suspended Solid and Chemical Oxygen Demand in Owan river. The pollution of the rivers could be attributed to influx through runoff of microorganisms from vegetation decay, municipal sewage, garbage, domestic and fecal waste into the rivers, especially during the wet season. This calls for a need in the periodic monitoring of the water bodies so as to prevent or minimize the pollution of these rivers in the future.
\end{abstract}

Keywords: Microbial, Physico-Chemical, Variation, Rivers

\section{Introduction}

The primary purpose of water analysis is to determine the suitability of water for a proposed use. The three main classes of use are domestic (household), agricultural and industrial, and hence, varying water quality is expected for these different uses [2]. The accumulation of toxic compounds, such as chemical pollutants and trace metals, from water runoff, especially during the wet season can result in downstream bioaccumulation and toxicity [22]. Similarly, bacteria loading to rivers and streams in urban and rural areas has been well documented as one of the most common pollutants affecting aquatic systems $[7,26]$.

Chemical contaminants or pollutants in the aquatic environment can be divided into four groups, viz: the plant nutrients, the oxygen consuming substances, the inorganic substances including some anions and heavy metals; and the organic compounds. While the first two groups are not directly harmful to aquatic life, the last two groups especially the heavy metals and most organic compounds constitute the environmental refectories (not usually eliminated from the environment by natural degradation) and with direct toxicity to aquatic life $[19,24,29]$. Of particular concern to environmental toxicologists are those compounds, which accumulate in the tissues, from often undetectable concentrations in water; organisms may accumulate levels of biological significance (bioaccumulation).

Furthermore, these compounds are passed along the food chain so that top carnivores feeding on contaminated prey may accumulate enormous concentration of these toxic subtances [5, 23]. These comprise of substances such as nitrates, phosphates, and sulphates, which are not directly harmful to aquatic life but may significantly upset the ecosystem. Water pollution problems associated with this 
group result from eutrophication- excessive nutrients enrichment that promotes unrestricted growth of aquatic plant biomas [3, 23].

The over production of higher tropic level biomas and subsequent decay of dead plants could lead to oxygen depletion, fish kills and development of anaerobic zones where bacteria actions produce foul odours and taste $[6,28]$. Accelerated eutrophication of this nature has been associated with the death of literally millions of fish in Escembia Bay, Florida and with the decline of certain fish species in lake Erie. Other notable examples have occured in lake Washington in Seattle, Madison lake in Wisconsin and lake Zurich in Switzerland [2].

One of the major biological effects of eutrophication resulting in financial loss is the stimulation of algae growth, especially in water supply reserviors. Large population of algae and in some cases the zooplankton which they support, may result in blocking of filters in water treatment works [10, 29]. The algae blooms associated with excessive amounts of nutrients have other consequences for the aquatic ecosystem. Some algae at high densities produce toxins, which kill fish. In Norfolk Broad lake, it was reported that Prymnesium parvum has caused several large fish kills over the last two decades [2]. Problems of eutrophication can support dense growth of aquatic weeds, which impede the flow of water and block waterways.

Nitrogen and Phosphorous are two nutrients most implicated in eutrophication and, because growth is normally limited by phosphorous rather than nitrogen, it is the increase in phosphorous that stimulates excessive plant production in fresh water. These nutrients are released into the water body during the breakdown of organic matter. Other important sources include phosphorous containg detergents (much of this entering the river in sewage effluent), agricultural runoff and leaching of artificial fertilizers, the burning of fossil fuels, etc, [8, 20, 22].

Effluents containing biodegradable organic chemicals generally act as pollutants not because they contain chemicals at concentrations that are toxic but they contain chemicals that provide food for micro-organisms which multiply rapidly as a result of increased food input [7]. The microorganism in the process of growing and oxidizing the organic chemical foodstuff use up the dissolved oxygen in water rapidly which in some cases, result into oxygen sag-a situation of dissolved oxygen depletion [1, 10]; and could cause the death of higher organisms like fish [4, 21]. A simple measure of the potential of organic matter for deoxygenating water is given by the biochemical oxygen demand (BOD). Its counterpart, the chemical oxygen demand (COD), which is always higher than the BOD, results from chemical oxidation of both organic and inorganic constituents in water utililizing the dissolved oxygen [6].

Sources of such oxygen consuming matters in the aquatic system include domestic effluents, industrial effluents, farm effluents run off and decay of plants after eutrophication [11]. Effluents containing degradable organic matter will also contain large amount of suspended solids, which cut out the light immediately below the discharge, thus eliminating photosynthetic organisms. Suspended solids also settle on the streambed altering the nature of the substratum and smothering many organisms living within it $[7,19]$.

\section{Materials and Methods}

\subsection{Study Area}

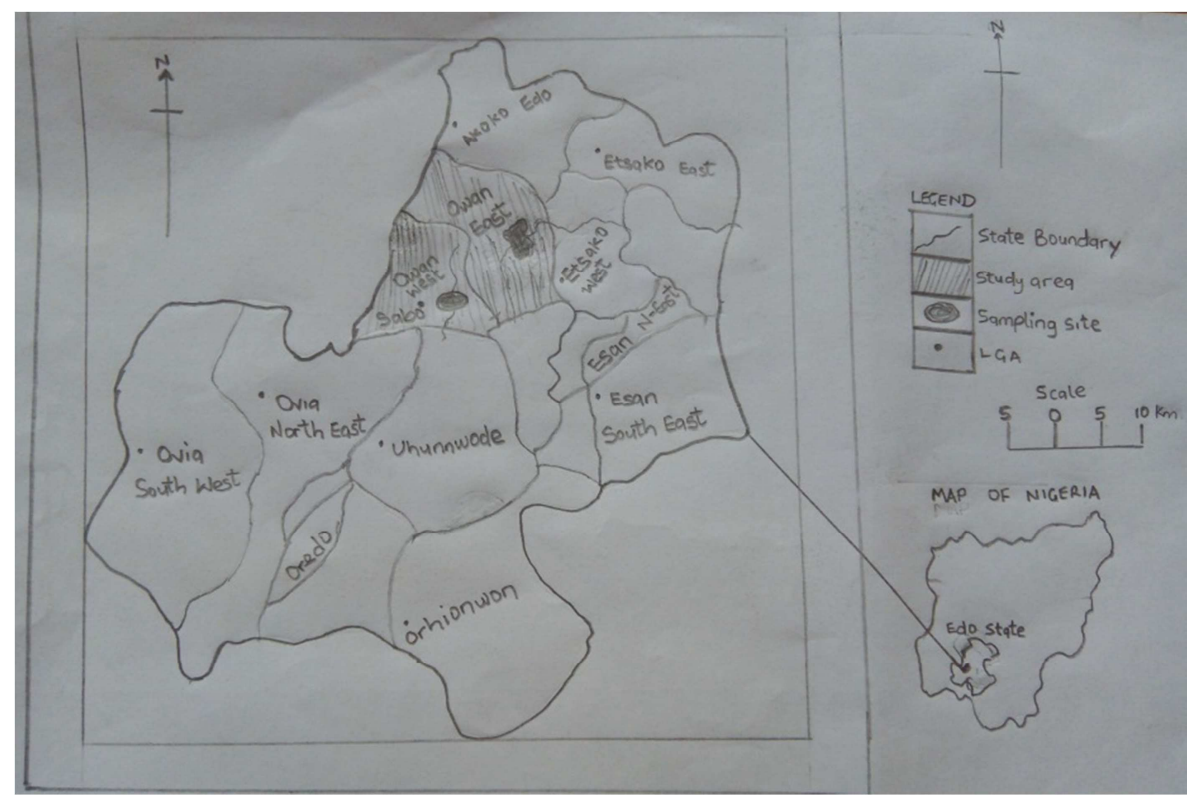

Figure 1. Map of Edo State showing Sampling Locations. 
Area of Edo State, Nigeria. Owan river serves as drinking water source for most of the villagers even though it is a washing zone for automobiles of all sorts on daily basis while a major market site is located near the bank of river Evbiobe; thus exposing the rivers to high level of pollution. Also, fishing activities are practiced in this area as a source of income and livelihood while the major occupation of the people is farming with the use of fertilizer; a practice that could lead to water pollution if the farm land is eroded into the rivers by storm water, especially during the raining season. Figure 1 depicts the map of the study area.

\subsection{River Water Sampling}

Samples of river water from randomly selected locations (ten sampling points) were collected within the study area. All sampling points were, however, geo-referenced using Garmin's eTrex 12 channel GP. At every sampling point, the sampling containers were thoroughly washed with the water sample before final collection. Samples for different parameters were taken and preserved as prescribed by $[3,5,20]$.

\subsection{Water Physico-Chemical Analysis}

Parameters such as temperature, $\mathrm{pH}$, conductivity and dissolved oxygen in water samples were measured in-situ on the field using portable meters and kits. Temperature, $\mathrm{pH}$ and conductivity were measured with Hanna combined temperature, $\mathrm{pH}$ and conductivity meter; while dissolved oxygen was measured with Hanna dissolved oxygen kit using the Winkler alkaline-azide titration method. Other physicochemical parameters were analyzed in the laboratory using methods prescribed by $[3,5,20]$. Data generated from the investigation were statistically tested for differences in sampling periods, spatial and seasonal variation using the student's t-test (ANOVA).

\subsection{Water Microbial Analysis}

The water samples collected in batches of $250 \mathrm{ml}$ into sterile $500 \mathrm{ml}$ screw-capped bottles were analysed in accordance with standard procedures described by $[5,26]$.

Total Viable Count (Aerobic Plate Count)

A $1 \mathrm{ml}$ of the water sample was transferred with sterile pipette into sterile Petri dish and nutrient agar was poured over the inoculums. Each Petri dish was gently rocked to ensure uniform distribution of the water sample. When the agar had solidified, the plates were incubated at $37 \mathrm{C}$ for 48hours. After which, the microbial count was determined by employing a Colony Counter.

Detection of coli form

Using the multiple tube technique of presumptive coli form count or total coli form, the following mixtures of the test water and the lactose were used. Five $10 \mathrm{ml}$ water quantities each in $10 \mathrm{ml}$ double strength medium, five $1 \mathrm{ml}$ water quantities each in $5 \mathrm{ml}$ single strength medium were incubated at $37^{\circ} \mathrm{C}$ for 24hours. The production of acid and gas after 24 or 48 hours incubation were considered to be positive. The confirmation test for the presence of coli form in the presumptive positive tubes was carried out by sub culturing aliquots of water from these tubes into brilliant green lactose bile broth (BGLB) and incubated at $37^{\circ} \mathrm{C}$ for 48 hours. The production of acid and gas at the end of the incubation period confirmed test as positive. After which, the number of micro-organisms grown on the plate was determined by a Colony Counter.

\section{Results and Discussion}

\subsection{Rivers Water Microbial Characteristics}

The mean microbiological status of the Owan river are presented in Tables 1 and 2 while the Evbiobe river microbial mean values are displayed on Tables 3 and 4 for dry and wet seasons respectively.

Table 1. Owan river microbial characteristic mean values (Dry season).

\begin{tabular}{|c|c|c|c|c|c|c|c|c|c|c|c|}
\hline Parameters & OB1 & OB2 & OB3 & OB4 & OB5 & OB6 & OB7 & OB8 & OB9 & OB10 & NIS (2007) \\
\hline Total Bact. Count (cfu/mL) & 4.23 & 3.94 & 4.60 & 3.92 & 4.51 & 4.02 & 3.87 & 4.30 & 4.16 & 4.48 & 103 \\
\hline Total Coli form (MPN/100mL) & 1.60 & 1.35 & 0.97 & 1.08 & 1.62 & 1.10 & 0.93 & 1.25 & 1.23 & 1.13 & NIL \\
\hline E. Coli Count (MPN/100mL) & 1.75 & 1.12 & 0.84 & 1.05 & 1.36 & 0.92 & 0.98 & 1.24 & 1.10 & 0.98 & NIL \\
\hline
\end{tabular}

(TBC, TCF, E.coli ) $\times 10^{2 *} \mathrm{n}=3$

Table 2. Owan river microbial characteristic mean values (Wet season).

\begin{tabular}{|c|c|c|c|c|c|c|c|c|c|c|c|}
\hline Parameters & OB1 & OB2 & OB3 & OB4 & OB5 & OB6 & OB7 & OB8 & OB9 & OB10 & NIS (2007) \\
\hline Total Bact. Count (cfu/mL) & 3.26 & 4.11 & 4.05 & 3.80 & 2.92 & 3.35 & 3.12 & 2.74 & 3.26 & 4.51 & $10^{3}$ \\
\hline Total Coli form (MPN/100mL) & 7.42 & 6.15 & 8.33 & 6.71 & 6.28 & 6.10 & 8.05 & 7.76 & 8.18 & 6.53 & NIL \\
\hline E. Coli Count (MPN/100mL) & 2.23 & 2.47 & 3.11 & 2.12 & 2.80 & 1.94 & 2.34 & 2.19 & 3.65 & 2.49 & NIL \\
\hline
\end{tabular}

TBCx $10^{3} ;$ (TCF and E. coli) $\times 10^{2} * \mathrm{n}=3$

Table 3. Evbiobe river microbial characteristic mean values (Dry season).

\begin{tabular}{|c|c|c|c|c|c|c|c|c|c|c|c|}
\hline Parameters & OB1 & OB2 & OB3 & OB4 & OB5 & OB6 & OB7 & OB8 & OB9 & OB10 & NIS (2007) \\
\hline TotalBact. Count (cfu/mL) & 8.37 & 9.21 & 9.14 & 8.75 & 9.02 & 8.71 & 8.60 & 8.44 & 9.12 & 8.89 & $10^{3}$ \\
\hline Total Coli form (MPN/100mL) & 5.15 & 4.82 & 6.78 & 5.11 & 6.23 & 4.12 & 5.99 & 5.35 & 6.64 & 6.47 & NIL \\
\hline E. Coli Count (MPN/100mL) & 1.08 & 1.17 & 1.20 & 0.93 & 1.01 & 1.34 & 1.23 & 1.16 & 0.89 & 0.95 & NIL \\
\hline
\end{tabular}

(TBC, TCF, E.coli ) $\times 10^{2 *} \mathrm{n}=3$ 
Table 4. Evbiobe river microbial characteristic mean values (Wet season).

\begin{tabular}{|c|c|c|c|c|c|c|c|c|c|c|c|}
\hline Parameters & OB1 & OB2 & OB3 & OB4 & OB5 & OB6 & OB7 & OB8 & OB9 & OB10 & NIS (2007) \\
\hline Total Bact. Count (cfu/mL) & 1.10 & 1.13 & 1.02 & 1.27 & 1.28 & 1.06 & 1.02 & 1.15 & 1.31 & 1.22 & $10^{3}$ \\
\hline Total Coli form (MPN/100mL) & 1.76 & 1.05 & 1.45 & 1.16 & 1.72 & 1.31 & 1.52 & 1.26 & 1.44 & 1.69 & NIL \\
\hline E. Coli Count (MPN/100mL) & 0.31 & 0.51 & 0.28 & 0.33 & 0.37 & 0.25 & 0.46 & 0.29 & 0.40 & 0.37 & NIL \\
\hline
\end{tabular}

TBCx $10^{4} ;\left(\mathrm{TCF}\right.$ and E. coli) $\times 10^{3} * \mathrm{n}=3$

The results obtained from Owan river analysis revealed that the mean values of total heterotrophic bacteria count, total coli form and Escherichia coli cells for the dry season's study ranged from $3.87 \times 10^{2}-4.60 \times 10^{2} \mathrm{cfu} / \mathrm{mL}, 0.93 \times 10^{2}$ $1.62 \times 10^{2} \mathrm{MPN} / 100 \mathrm{~mL}$ and $0.84-1.75 \times 10^{2} \mathrm{MPN} / 100 \mathrm{~mL}$ respectively. The respective wet season values obtained from Owan river for the total heterotrophic bacteria count, total coli form and Escherichia coli cells ranged from $2.74 \times 10^{3}$ $4.51 \times 10^{3} \mathrm{cfu} / \mathrm{mL}, \quad 6.10 \times 10^{2}-8.33 \times 10^{2} \quad \mathrm{MPN} / 100 \mathrm{~mL}$ and $1.94 \times 10^{2}-3.65 \times 10^{2} \mathrm{MPN} / 100 \mathrm{~mL}$. Higher values of these parameters were recorded in the surface water samples during the wet season's study. The higher values obtained during the wet season as compared to the dry season could be attributed to influx through runoff of microorganisms originating from vegetation decay, municipal sewage, garbage, domestic and fecal waste into the Owan river. Heterotrophic microorganisms include both members of the natural (typically non-hazardous) microbial flora of water environments and organisms present in a rangeof pollution sources $[14,15,26]$. Enteropathogenic E. coli are enteric organisms, and humans are the major reservoir. Livestock, such as cattle and sheep and, to a lesser extent, goats, pigs and chickens, are a major source. They have also been associated with raw vegetables, such as bean sprouts and the pathogens have been detected in a variety of water environments $[15,26]$.

It is not surprising that elevated loads of these microbes were recorded in Evbiobe river when compared with owan river for both dry and wet seasons since Evbiobe river is always contaminated with organic materials eroded into the water body from a major market located behind the river. The waste (blood, bones and pieces of flesh) from the slaughters' tables and discarded food stuffs including decomposing vegetables amongst others are major contributing factors of the river microbial pollution $[7,26]$. Bacteria of greatest concern in drinking water are those that originate from the gut of warm-blooded animals [26]. Sources include waste generated from wildlife, pets, and slaughter's tables/vicinity in market squares and livestock on farms or in feedlots. Contamination problems arise from improperly designed, failing, or overloaded waste water treatment systems, including septic systems from private homes, and leaking sanitary sewer pipes. Human sources are of particular concern as they include bacteria of human origin and may include human pathogens [7]. Floodwater commonly contains high levels of bacteria from numerous sources.

The Total bacteria counts (TBC) for Owan and Evbiobe rivers during the dry season were lower than the limit values specified by Nigeria Industrial Standard for domestic water $[14,15]$. While the TBC values recorded in Owan river during the wet season were within the NIS baseline values and higher than the NIS guideline values were observed in Evbiobe river wet season results (Tables 1 to 4). Generally, the total coli form and Escherichia coli cells present in both rivers represent high bacteria load compared to the recommended standards for drinking water $[12,13,14,15$, 30]. This condition constitutes a threat to end users as the water is unsafe for human consumption with respect to bacteriological loads, thus suggesting adequate disinfection process before distribution for local consumption, domestic and industrial usage. The recovery of viable indicator bacteria from the rivers in intolerable numbers constitute a serious hazard to public health, as their presence is indicative of a possible presence of micro organisms associated with water-borne diseases [26]. Such micro organisms include Salmonella typhi, Salmonella paratyphi, Vibrio choleae, Entheropathogenic Escherichia coli and enteric viruses. Waterborne transmission of pathogenic $E$. coli has been well documented forrecreationalwaters and contaminated drinking-water. A well publicized waterborne outbreakof illness caused by E. coli O157:H7 (and Campylobacter jejuni) occurred in thefarming community of Walkerton in Ontario, Canada. The outbreak took place inMay 2000 and led to 7 deaths and morethan 2300 illnesses. The drinkingwater supplywas contaminated by rainwater runoff containing cattle excreta [15].

However, the presence of bacteria does not mean the water is unsafe to drink. Only disease-causing bacteria, known as pathogens, lead to the outbreak of disease. Total coliform bacterials a group of different kinds of bacteria commonly found in the environment, including soil, vegetation and untreated surface water. Total coliform bacteria are generally not harmful. Fecal coliform bacteria are a subgroup of the total coliform group and they exist in great quantities in the intestines and feces of humans and animals [7;27]. The presence of fecal coliform bacteria in drinking water is a strong indication of recent sewage or animal waste contamination, which should be interpreted as an indication that there is a greater risk that pathogens are present. Microbes in these wastes may cause short-term effects, such as diarrhea, cramps, nausea, headaches or other symptoms, as well as potentially pose long-term health effects. They may pose a special health risk for infants, young children, some of the elderly and people with severely compromised immune systems [26].

Most aquatic bacteria are free-living and perform beneficial functions such as thedecomposition of organic matter. A few species are opportunistic pathogens and causediseases in fish, particularly under conditions of stress and immune deficiency. Symptoms of most bacterial diseases 
include fish not feeding well and swimming erratically. Stressed fish are highly susceptible to outbreaks of pathogenic bacteria. Low levels of dissolved oxygen, thermal stress, high concentrations of nitrogenous metabolites and improper handling are the principal causes which render fish susceptible to bacterial diseases $[9,30]$. However, there is no information in the scientific literature to show that E.coli affects the growth, reproduction, health or survival of fish. In India, for instance fish are cultured in sewage ponds, with no detrimental effects. However, fish grown in waste water harbour micro-organisms, some of which arepathogenic and may infect consumers and handlers [9].

\subsection{River Water Physico-Chemical Parameters}

Table 5. Mean range values and Statistical analysis of Owan water physico-chemical parameters.

\begin{tabular}{|c|c|c|c|c|c|c|}
\hline Parameters & Range & Overall mean & Std Dev. & $\mathrm{CV} \%$ & $T$ cal & Fp cal \\
\hline Temp. $\left({ }^{\circ} \mathrm{C}\right)$ & $27.39-30.60$ & 30.16 & 1.88 & 6.25 & $6.548 *$ & 0.812 \\
\hline Colour (Pt/Co unit) & $12.67-25.00$ & 19.04 & 5.13 & 26.96 & $-2.669 *$ & 0.918 \\
\hline Turbidity (FTU) & $4.13-6.83$ & 5.48 & 1.63 & 29.74 & $-6.756^{*}$ & 0.224 \\
\hline Cond. (uS/cm) & $118.60-194.80$ & 147.47 & 4.03 & 27.15 & $6.252 *$ & 0.287 \\
\hline TD. Solid (mg/1) & $76.54-104.05$ & 86.99 & 16.09 & 18.50 & $4.167 *$ & $6.064 *$ \\
\hline TS. Solid (mg/l) & $2.64-5.70$ & 4.55 & 3.77 & 82.86 & -1.224 & 0.403 \\
\hline T. Solid (mg/l) & $80.93-107.56$ & 91.54 & 15.57 & 17.01 & $4.138 *$ & $6.196^{*}$ \\
\hline Acidity $\left(\mathrm{mg} / 1 \mathrm{CaCO}_{3}\right)$ & $5.37-7.60$ & 6.42 & 0.05 & 16.34 & $-7.351 *$ & 0.012 \\
\hline T. Alkal. $\left(\mathrm{mg} / \mathrm{l} \mathrm{CaCO}_{3}\right)$ & $106.67-143.30$ & 122.64 & 18.41 & 15.01 & $4.741 *$ & 0.082 \\
\hline T. Hard. $\left(\mathrm{mg} / 1 \mathrm{CaCO}_{3}\right)$ & $54.67-69.67$ & 61.12 & 8.45 & 13.83 & $4.341 *$ & 0.119 \\
\hline $\mathrm{Ca}^{2+}(\mathrm{mg} / \mathrm{l})$ & $17.91-21.28$ & 19.30 & 2.18 & 11.31 & $2.874 *$ & 1.733 \\
\hline $\mathrm{Mg}^{2+}(\mathrm{mg} / \mathrm{l})$ & $5.71-9.21$ & 6.42 & 1.55 & 24.19 & $3.244^{*}$ & 1.911 \\
\hline DO (mg/l) & $5.97-8.47$ & 7.23 & 1.18 & 16.36 & $-8.207^{*}$ & $5.522 *$ \\
\hline BOD (mg/l) & $3.93-7.03$ & 5.64 & 1.10 & 19.49 & $-10.959 *$ & 0.993 \\
\hline $\mathrm{Cl}^{-}(\mathrm{mg} / \mathrm{l})$ & $18.47-30.41$ & 24.15 & 2.49 & 10.31 & $19.099 *$ & 1.278 \\
\hline $\mathrm{NO}_{3}^{-}(\mathrm{mg} / \mathrm{l})$ & $8.77-15.81$ & 12.15 & 2.81 & 22.49 & $-10.447 *$ & 0.185 \\
\hline $\mathrm{NO}_{2}^{-}(\mathrm{mg} / \mathrm{l})$ & ND-0.09 & 0.05 & 0.52 & 108.33 & $-4.502 *$ & 0.038 \\
\hline $\mathrm{PO}_{4}{ }^{3-}(\mathrm{mg} / \mathrm{l})$ & $11.23-24.25$ & 17.09 & 5.18 & 30.31 & $10.198 *$ & $2.914 *$ \\
\hline $\mathrm{SO}_{4}{ }^{2-}(\mathrm{mg} / \mathrm{l})$ & $29.37-75.15$ & 51.54 & 10.71 & 20.78 & $19.869 *$ & 1.231 \\
\hline
\end{tabular}

$\mathrm{CV}=$ Coefficient of variation, $\mathrm{t}$ cal $=\mathrm{t}$ values calculated for test of sig. difference between dry and wet seasons, Fp cal $=\mathrm{F}$ values calculated for test of sig. variation between sampling periods, * Significant at $\mathrm{P}<0.05$.

Table 6. Mean range values and Statistical analysis of Evhoebe water physico-chemical parameters.

\begin{tabular}{|c|c|c|c|c|c|c|}
\hline Parameters & Range & Overall mean & Std Dev. & $\mathrm{CV} \%$ & $T$ cal & Fp cal \\
\hline Temp $\left({ }^{\circ} \mathrm{C}\right)$ & $27.87-31.17$ & 29.55 & 1.65 & 5.58 & $18.434 *$ & 0.550 \\
\hline Colour (Pt/Co unit) & $9.00-20.00$ & 14.47 & 5.94 & 41.05 & $3.536^{*}$ & $2.492 *$ \\
\hline Turbidity (FTU) & $4.20-6.03$ & 5.07 & 0.85 & 16.77 & $-10.899 *$ & 1.031 \\
\hline Cond. (uS/cm) & $123.03-145.40$ & 132.93 & 12.82 & 9.64 & $-10.521^{*}$ & 1.429 \\
\hline TD. Solid (mg/l) & $49.27-64.31$ & 57.55 & 5.57 & 9.68 & $6.776^{*}$ & 0.068 \\
\hline TS. Solid (mg/l) & $2.71-4.45$ & 3.68 & 0.69 & 18.75 & $-3.668^{*}$ & 0.724 \\
\hline T. Solid (mg/l) & $52.49-66.77$ & 61.01 & 5.39 & 8.83 & $6.880 *$ & 0.925 \\
\hline Acidity $\left(\mathrm{mg} / \mathrm{l} \mathrm{CaCO}{ }_{3}\right)$ & $7.95-9.37$ & 8.73 & 0.57 & 6.52 & $-8.711 *$ & $3.473 *$ \\
\hline T. Alkal. $\left(\mathrm{mg} / 1 \mathrm{CaCO}_{3}\right)$ & $85.67-108.33$ & 97.57 & 9.40 & 9.63 & $16.184 *$ & 0.572 \\
\hline T. Hard. $\left(\mathrm{mg} / 1 \mathrm{CaCO}_{3}\right)$ & $67.33-96.00$ & 81.48 & 12.64 & 15.51 & $9.576^{*}$ & 0.081 \\
\hline $\mathrm{Ca}^{2+}(\mathrm{mg} / \mathrm{l})$ & $19.44-28.12$ & 23.46 & 3.95 & 16.84 & $6.107^{*}$ & 1.129 \\
\hline $\mathrm{Mg}^{2+}(\mathrm{mg} / \mathrm{l})$ & $9.20-13.33$ & 11.28 & 1.77 & 22.87 & $6.642 *$ & 0.426 \\
\hline DO (mg/l) & $6.50-9.17$ & 7.74 & 1.02 & 13.18 & $-10.928^{*}$ & 0.081 \\
\hline BOD (mg/l) & $5.00-7.40$ & 6.14 & 0.94 & 15.31 & $-9.623 *$ & $4.325^{*}$ \\
\hline $\mathrm{NO}_{3}^{-}(\mathrm{mg} / \mathrm{l})$ & $19.75-27.23$ & 23.55 & 3.02 & 12.82 & $-10.163^{*}$ & $1.892 *$ \\
\hline $\mathrm{NO}_{2}^{-}(\mathrm{mg} / \mathrm{l})$ & $0.02-0.05$ & 0.03 & 0.02 & 66.67 & $-2.791 *$ & 1.359 \\
\hline $\mathrm{PO}_{4}{ }^{3-}(\mathrm{mg} / \mathrm{l})$ & $10.56-17.39$ & 13.75 & 2.95 & 21.45 & $9.616^{*}$ & 0.869 \\
\hline $\mathrm{SO}_{4}{ }^{2-}(\mathrm{mg} / \mathrm{l})$ & $4.52-6.63$ & 5.55 & 0.94 & 16.94 & $7.736^{*}$ & $7.893 *$ \\
\hline
\end{tabular}

$\mathrm{CV}=$ Coefficient of variation, $\mathrm{t}$ cal $=\mathrm{t}$ values calculated for test of sig. difference between dry and wet seasons, Fp cal $=\mathrm{F}$ values calculated for test of sig. variation between sampling periods, * Significant at $\mathrm{P}<0.05$.

Tables 5 and 6 depict the mean values and statistical analysis of the physico-chemical parameters of Owan and Evbiobe river water for both dry and wet seasons respectively.
The results of the statistical analysis; which include the range, the overall mean standard deviation and coefficient of variation for the two rivers are shown on the Tables. 
The student t-test conducted on the results revealed high level of significant difference $(p<0.05)$ between wet and dry seasons' values for all parameters except TSS and COD in Owan river, whereas no significant variation was recorded within the sampling period for both rivers as revealed by $\mathrm{F}_{\mathrm{p}}$ cal values (Tables 5 and 6). This implies that most of the physico-chemical characteristic properties of the rivers water varied with season. This observation is typical of most surface water as reported by many authors [3, 17, 20, 24]. Although the coefficient of variation was high for TSS $(82.86 \mathrm{mg} / \mathrm{l})$ in Owan river and $\mathrm{NO}_{3}{ }^{-}(108.33 \mathrm{mg} / \mathrm{l}$ and $66.67 \mathrm{mg} / \mathrm{l}$ ) for the two rivers respectively, however, variation among sampling point was generally low as shown in the calculated values of coefficient of variation, implying that each set of the water samples were collected from a single source of similar physico-chemical characteristics, which are mostly influenced by the geology of the area.

The Temperature for the combined wet and dry seasons of Owan river ranged from $27.39-30.60^{\circ} \mathrm{C}$ with overall mean value of $30.16^{\circ} \mathrm{C}$ while Evbiobe river had higher temperature range of $27.87-31.17^{\circ} \mathrm{C}$, with an overall mean value of $29.54^{\circ} \mathrm{C}$. The relatively high temperature variation is in response to time and period of sample collection; hence, results of wet season were lower than those for the dry season. This observation is in concordance with what [6] earlier reported for Ondo coaster waters [3], for surface waters, [18] for Ogba river in Benin city, [19] for Ikpoba river in Benin city and [20] for Owena dam in Ondo state.

The mean colour units of the Owan and Evbiobe water samples ranged from 12.67 - $25.00 \mathrm{Pt} / \mathrm{Co}$ units and 9.00$20.00 \mathrm{Pt} / \mathrm{Co}$ units; with overall mean of $19.04 \mathrm{Pt} / \mathrm{Co}$ units and $14.47 \mathrm{Pt} / \mathrm{Co}$ units respectively. High values of this water quality parameter measured during the wet season compared to the dry season's data can be attributed to run-off into the water bodies.

Conductivity of the Owan and Evbiobe rivers water ranged from 118.60 - $194.80 \mu \mathrm{S} / \mathrm{cm}$; 123.03-145.40 with an overall mean value of $147.47 \mathrm{uS} / \mathrm{cm}, 132.93 \mathrm{uS} / \mathrm{cm}$ respectively. Generally, low values of conductivity and TDS measured in the rivers water reflect freshness of the water, since fresh waters are characterized by low conductivity [20].

The $\mathrm{pH}$ of the water samples ranged from very slightly acidic value of 6.25 to a neutral value of 7.32 for Owan river, while Evbiobe river recorded $\mathrm{pH}$ values of slightly acidic to weak alkaline range (6.33-8.20). A measured $\mathrm{pH}$ change provides a very useful indication that some biogeochemical effect has caused the buffer capacity of a water body to be exceeded. Possible causes of a decrease in the measured $\mathrm{pH}$ include the intentional or accidental release of stronglyacidic waste into a stream; the influence of acid rain, bacterial nitrification, or sulfate reduction; and the release of acid mine drainage water. Increases in $\mathrm{pH}$ may be caused by acceleratedalgal growth, such as that which may occur during an algal bloom (when pH canexceed 10) and denitrification. Lower wet season $\mathrm{pH}$ values for the rivers water were found to be consistent with the findings reported by many workers $[3,18,19,20,29]$.
The mean value of nitrate $\left(\mathrm{NO}_{3}{ }^{-}\right)$in the water samples ranged from 8.77 - $15.81 \mathrm{mg} / \mathrm{l}$ for Owan river and 19.75 $27.23 \mathrm{mg} / 1$ for Evbiobe river. The results from this study revealed that both rivers have been impacted by nitate causing materials from anthropogenic activities, especially the Evhoebe river that is implicated by its location. This was observed from the higher value of nitrate recorded in Evbiobe river water than Owan river. Nevertheless the rivers are not yet referred polluted in this regard as they are well below the guideline values. Therefore, suggesting that the water from both rivers are safe for drinking with respect to nitrate concentration. The concentrations of phosphate measured in Owan and Evbiobe rivers water ranged from $11.23-24.25 \mathrm{mg} / \mathrm{l}$ and $10.56-17.39 \mathrm{mg} / \mathrm{l}$ respectively. Phosphorus from where phosphate is derived occurs widely in nature in plants, in micro-organisms, in animal wastes andso on. Large quantities of phosphate are applied as fertilizers in agriculture, and runoff from these areas often contains elevated concentrations of phosphate [8, 24]. Typical phosphate concentrations in surface waters is usually $<5 \mathrm{mg} / \mathrm{L}$ and more in nutrient- enriched waters, although 0.10 $\mathrm{mg} / \mathrm{L}$ is the recommended maximum concentration for rivers and streams [9, 28]. Thus, the mean phosphate values recorded in the rivers water were above the recommended maximum concentration. The significance of phosphorus in water is principally in regard to the phenomenon of eutrophication (over-enrichment) of lakes and rivers.

High sulphate concentrations range of $29.37-75.15 \mathrm{mg} / \mathrm{L}$ were recorded for Owan water samples as compared to very low values $(4.02-7.40 \mathrm{mg} / \mathrm{L})$ observed for Evbiobe river. The levels of this parameter in the water samples for both rivers are well below the stipulated value of $250 \mathrm{mg} / \mathrm{L}$ drinking water standards $[12,13,28]$. The sources of this parameter in the water could be associated with soil mineralogy in Evbiobe river while possible contribution from anthropogenic activities and soil mineralogy could be responsible for the loads in Owan river. The high values recorded in Owan river is not surprising as the water body serves as a washing zone for automobiles of all sorts on daily basis, even though is also a drinking water source; thus exposing the rivers to high level of contamination from sulphur-containing detergents.

\section{Conclusion}

The values of $\mathrm{pH}$, colour, turbidity, DO; BOD, COD, nitrate, nitrite, phosphate, and sulphate were higher during the wet season than in the dry season, while others like Conductivity, chloride, hardness, total solids had higher during the dry season values over the wet season. This observation could be attributed to a combination of water runoff with suspended particles into the rivers during the wet season and local concentration from excessive evaporation in the dry season, thereby increasing the dissolved solids. Significant difference $(\mathrm{P}<0.05)$ between the wet and dry season exists among most of the parameters. All the parameters analyzed provided concentration below their 
guideline values except colour, turbidity, and BOD. Although, the rivers water is fairly good for drinking and for other domestic purposes in this regard, there is a need for periodic monitoring of the water source in respect of those parameters that concentrated more than their limit. This research has furnished some vital information on the current quality status of river Owan and Evbiobe; hence the results obtained will further serve as basis for future monitoring of the study area.

\section{References}

[1] Adefemi, O. S.; Olaofe, O. and Asaolu, S. S. (2007). Seasonal Variation in Heavy metal Distribution in sediments of major Dams in Ekiti State. Pak. J. Nutr. 6 (6), 705-707.

[2] Aiyesanmi, A. F., Ipinmoroti, K. O. and Adeeyinwo, C. E. (2006); Baseline water quality status of rivers within okitipupa southeast belt of the bituminous sands field of Nigeria. Nig. J. Sci. 40, 62-71.

[3] Aiyesanmi, A. F., Oguntuase, A. A. and Idowu, G. A. (2010). Investigation on speciation and pollution index of heavy metals in river Ala sediment, Akure, Nigeria. Intern. J. Bio. Chem. Sci. 4 (6) 2348-2349.

[4] Amoo I. A., Adebayo O. T. and Lateef A. J. (2005). Evaluation of heavy metals in Fishes, water and sediments of Lake Kainji, Nigeria. Journal of Food, Agriculture and Environ. 3 (1): 209-212.

[5] APHA (1998). Standard Methods for the Examination of Water and Wastewater, 20th ed. American Public Health Association, American Water Works Association, Water Polition Control Federation, Washington, USA.

[6] Asaolu, S. S. (2003). Determination of some heavy metals in Oreochromis niloticus, Clariasgariepinus and Synodontisspp from the coastal water of Ondo State, Nigeria. Pak. J. Sci. Ind. Res. 45 (1) 17-19.

[7] Dhana S. and Balamurugan R. M. (2017). Ecological sanitation relative efficiency of different composting materials and recovery of nutrient for ecosan toilet. International Journal of Environmental science. 6 (1): 1-2.

[8] Dhanakumar, S., Murthy, K. R. and Mohanra, R. (2015). Phosphorous fractionation in surface sediments of the Cauvery Delta region, Southeast India. Environmental Management of River Basin. Pp 477-489.

[9] DWAF (Department of Water Affairs and Forestry), (1996). South African Water Quality Guidelines (second edition). Volume 6: Agricultural Water Use: aquaculture. pp 185.

[10] Efe, S. I., Ogban, F. E., Horsfall, M. Jnr, Akporhonor, E. E. (2005) Seasonal variations of physico-chemical characteristics in water resources quality in Western Niger Delta region, Nigeria. J. Appl. Sci. Environ. Mgt. 9 (1) 191-195.

[11] Engelking, P. (2003). Pollution. In: Microsoft Encarta Encyclopedia Delux 2003, (c) 1993-2002. Microsoft Corporation.

[12] EPA, (2001). Parameters of Water Quality: Interpretation and Standards. Environmental Protection Agency, Ireland. pp133.
[13] EU, (2002). The Commission of the European Communities: Commission regulation, (EC) No 221/2002 amending regulation (EC) No. 446/2001 setting maximum levels for certain contaminants in food stuff in order to rpotect public health. Official Journal of the European Communities 7. 2. 2002, L37/5-L37/6.

[14] Health Canada (2006a) Guidelines for Canadian drinking water quality: Guideline Technical Document Heterotrophic plate count. Water Quality and Health Bureau, Healthy Environments and Consumer Safety Branch, Health Canada, Ottawa, Ontario.

[15] Health Canada (2006b) Guidelines for Canadian drinking water quality: Guideline Technical Document - Escherichia coli. Water Quality and Health Bureau, Healthy Environments and Consumer Safety Branch, Health Canada, Ottawa, Ontario.

[16] McKelvie I. D. (2004). In situ measurement of physicochemical water quality parameters. In (Burden, F. R., Donnert, D., Godish, T. and McKelvie, I. D. Editors) Environmental Monitoring Handbook. McGraw-Hill pp3. 1-3. 21.

[17] Najafpour, S.; Alkarkhi, A. F. M.; Kadir, M. O. A.; Najafpour, G. D., (2008). Evaluation of spatial and temporal variation in river water quality. Int. J. Environ. Res., 2 (4), 349-358.

[18] Obasohan E. E. (2008). The use of heavy metals load as an indicator of the suitability of the water and fish of Ibiekuma stream for domestic and consumption purposes. Bioscience Research Communications, 20: 265-270.

[19] Oronsaye, J. A. O.; Wangboje, O. M. and Oguzie, F. A. (2010) Trace metals in some benthic fishes of the Ikpobariver dam, Benin City, Nigeria. African Journal of Biotechnology, 9: 8860-8864.

[20] Oyakhilome, G. I; Aiyesanmi, A. F. and Akharaiye F. C. (2012). Water Quality Assessment of the Owena MultiPurpose Dam, Ondo State, Southwestern Nigeria. Journ. Envir. Protect., 3 (1), pp14-25.

[21] Oyakhilome G. I.; Adefemi S. O.; Aiyesanmi A. F. and Asaolu S. S. (2013). Inter-relationship of heavy metals concentration in water, sediment and fish samples from Owena MultiPurpose Dam, Ondo State, Southern Nigeria. Journ. Emerging Trend in Eng. And App. Sc. (JETEAS). 4 (2): 207-215.

[22] Oyakhilome G. I.; Adefemi S. O.; Asaolu S. S.; Akinola O. K. (2014). Investigation of some Quality Parameters in Groundwater from Afuze, Edo State, Nigeria. Inter. Journal of Environmental Monitoring and Protection. Vol. 1, No. 4, pp. 62-67.

[23] Öztürk, M., Özözen, G., Minareci, O. and Minareci, E. (2009). Determination of heavy metals in fish, water and sediments of avsar dam lake in turkey. Iranian Journal of Environmental Health Science and Engineering, 6: 73-80.

[24] Pejman, A. H.; Nabi Bidhendi, G. R.; Karbassi, A. R.; Mehrdadi, N.; Esmaeili Bidhendi, M., (2009). Evaluation of spatial and seasonal variations in surface water quality using multivariate statistical techniques. International Journal of Environmental Science and Technology., 6 (3): 467-476.

[25] Roesner, L. A. and Bledsoe, B. P.: 2003, 'Physical Effects ofWetWeather Flows on Aquatic Habitats: Present Knowledge and Research Needs', Water Environment Research Foundation Technical Report \# 00-WSM-4. Alexandria, VA., pp. 1-197. 
[26] Simpson, J. M., Domingo, J. W. S. and Reasoner, D. J.: (2002) 'Microbial source tracking: State of the science', Environmental Science and Technology 36, 5279-5288.

[27] Stein, E., Ackerman, D. and Schiff, K.: 2003, 'Watershedbased Sources of Contaminants to San Pedro Bay and Marina del Rey: Patterns and Trends', Southern California Coastal Water Research Project Technical Report \#413, Westminster, CA, pp 1-33.

[28] USEPA (2009). "Drinking water standards and health advisories," EPA 822-R-09-011, Office of Water, US Environmental Protection Agency, Washington.
[29] Vincent-Akpu, I. F., Tyler A. N., Wilson C., Mackinnon G. (2015). Assessment of physico-chemical properties and metal contents of water and sediments of Bodo Creek, Niger Delta, Nigeria. Journal Toxicological \& Environmental Chemistry; 97: (2) 135-144.

[30] WHO. (2008). Guidelines for drinking - water quality, 3rd Ed. World Health Organisation 20 Avenue Appia, 1211 Geneva 27, Switzerland. Pp 1-688. 